\title{
A GESTÃO DEMOCRÁTICA DAS ESCOLAS: DO AUTOGOVERNO À ASCENSÃO DE UMA PÓS-DEMOCRACIA GESTIONÁRIA? ${ }^{1}$
}

\author{
Licínio C. Lima*
}

RESUMO: $\mathrm{O}$ autor assinala três elementos básicos que têm sido historicamente associados à gestão democrática das escolas: eleição, colegialidade, participação na decisão. A combinação ou rejeição de algumas dessas diferentes dimensôes, em contextos sociais específicos, pode resultar em várias concepçóes de gestão democrática das escolas, desde o autogoverno até à possível ascensão de uma pós-democracia gestionária.

Palavras-chave: Gestão democrática das escolas. Autogoverno. Participação no processo da tomada da decisão. Gerencialismo. Pós-democracia.

\section{DEMOCRATIC MANAGEMENT OF SCHOOLS: FROM SELF-GOVERNMENT TO THE RISE OF A MANAGERIAL POST-DEMOCRACY?}

ABSTRACT: The author points out three basic elements that have been historically associated with the democratic management of schools: election, collegiality, participation in decision-making. The combination or the rejection of some of those different dimensions in specific social contexts may result in various conceptions of democratic management of schools, from selfgovernment to the possible rise of a managerial post-democracy.

Keywords: Democratic management of schools. Self-government. Participation in the decision-making process. Managerialism. Post-democracy.

\section{LA GESTION DÉMOCRATIQUE DES ÉCOLES: DE L'AUTOGOUVERNEMENT À L'ÉMERGENCE D'UNE POST-DÉMOCRATIE GESTIONNAIRE?}

RÉSUMÉ: L'auteur souligne trois éléments de base qui ont été historiquement associés à la gestion démocratique des écoles: l'élection, la collégialité, la participation à la décision. La combinaison ou le rejet de certaines de ces différentes dimensions, dans des contextes sociaux spécifiques, peuvent

* Instituto de Educação da Universidade do Minho. Braga, Portugal. E-mail do autor: llima@ie.uminho.pt 
entraîner des diverses conceptions de la gestion démocratique des écoles, de l'autogouvernement à l'émergence d'une post-démocratie gestionnaire.

Mots-clés: Gestion démocratique des écoles. Autogouvernement. Participation au processus de prise de décision. Managérialisme. Post-démocratie.

\section{Introdução}

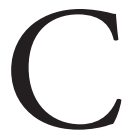

onsiderando a segunda metade do século XX, em países que, como Portugal e o Brasil, experimentaram durante longos períodos a vipolítico-educativo mais pleno de significado democrático e com maior potência transformadora do que aquele que, tendo sido assumido como utopia, reivindicação e palavra-de-ordem, foi expresso através da categoria "gestão democrática das escolas". Associada à democratização da educaçáo, incluindo a democratizaçáo do acesso, dos conteúdos e dos métodos, a valorização da condição social dos professores, a abertura à comunidade (GRÁCIO, 1986), a democratização do governo e do funcionamento das escolas representou uma dimensão central do próprio processo de democratização política. Com particular intensidade em certos momentos históricos, a democratização das organizações educativas e dos poderes escolares revela-se bastante para além de um simples resultado, mais ou menos mecânico, da democratização política, afirmando-se ainda como uma importante contribuição para a própria democratização dos regimes e das instituiçóes políticas, da sociedade e da cultura.

Em Portugal, por exemplo, antes mesmo da Revolução do 25 de abril de 1974, a gestão democrática das escolas representava já uma categoria do discurso político da oposição democrática e dos movimentos estudantis, uma reivindicação claramente expressa durante as crises universitárias da década de 1960, com repercussóes em toda a educação. Possivelmente mais do que no Brasil, dadas as diferenças do processo de transição para a democracia, registou-se, em Portugal, logo a partir dos primeiros dias que se seguiram à ação dos capitães (LIMA, 1999), uma rutura com as formas autocráticas de governo escolar que haviam sido estabelecidas ao longo de quase meio século. Em muitas escolas, sem qualquer período de transição e sem iniciativas anteriores por parte de associaçóes de pais ou de conselhos escolares minimamente participativos, ao invés do que terá ocorrido no Brasil (GHANEM, 2004, p. 119-132), assembleias de escola e reuniōes gerais de outros coletivos escolares decidiram depor antigos reitores e diretores nomeados pelo governo anterior, igualmente deposto, "saneando-os", como se dizia à época, e substituindo-os, à margem de qualquer enquadramento jurídico, ainda que mínimo, por órgãos colegiados de distinta designação e composição, em geral 
conhecidos por "comissóes de gestâo". (STOER, 1986; LIMA, 1988; 1992) Para esse efeito, adotaram-se diversas práticas revolucionárias e de democracia direta, convocando-se uma "legitimidade revolucionária" que concedia primazia e protagonismo aos atores educativos periféricos, frequentemente em luta entre si e em conflito com o governo central do país e a sua ação legislativa, mesmo quando esse invocava, e procurava exercitar na prática governativa, uma legitimidade revolucionária assente no Movimento das Forças Armadas. Mas nem o Programa do Movimento nem os programas dos primeiros governos provisórios consagravam o princípio da gestão democrática das escolas, o seu autogoverno ou a sua autogestão pedagógica. Como observou com pertinência Stephen Stoer (1986, p. 153), "A revolução impôs ao Estado a gestáo democrática nas escolas".

Em muitas escolas portuguesas, a imposição das práticas de gestão democrática por parte das periferias escolares perante os governos centrais - no contexto de uma administração do sistema escolar que nunca foi formalmente descentralizada durante o período revolucionário e, ainda, perante a ausência de um projeto de transferência de certos poderes para as escolas, pois o ministério da educação manteve a sua estrutura e ação centralistas -, constituíram práticas de autogoverno, definitivamente à margem das leis, mas que os governos provisórios, durante o período revolucionário, se viram forçados a aceitar, legalizando-as retrospetivamente logo através do Decreto-Lei no 221/74, de 27 de maio (PORTUGAL, 1974a) e, assim, contribuindo para a sua generalização a todas as escolas do país. E mesmo quando essa legislação procurava apenas, no plano das orientaçóes para a ação, reconhecer as comissóes de gestáo eleitas nas escolas, passando a aceitá-las como interlocutores legítimos com o governo mas, simultaneamente, limitando fortemente a sua capacidade de decisão através das competências que lhes eram destinadas, remetendo-as para a legislação do regime de Salazar-Caetano, os atores escolares ignoraram, por vezes de forma generalizada, tais limites e disputaram, no plano da ação organizacional, a direçâo das escolas com os governos centrais. Assumiram-se, dessa forma, como instâncias auto-organizadas, ensaiando práticas autonómicas e de democracia direta no interior das escolas, especialmente, embora não exclusivamente, através da ação dos professores e das suas decisóes, tomadas em reunióes plenárias.

Durante o período revolucionário, embora à margem dos conceitos de descentralização e de autonomia das escolas, que à época se mantinham ausentes dos discursos político-educativos, foi de um exercício autogestionário, de práticas de autogoverno e de uma autonomia de facto que, certamente, se tratou, configurando uma espécie de aceleração revolucionária que só mais tarde viria a ocorrer, com traços semelhantes, noutros domínios da vida portuguesa, designadamente durante o ano de 1975.

Como veremos seguidamente, a gestão democrática das escolas é uma complexa categoria político-educativa, uma construção social que não dispensa a 
análise dos contextos históricos, dos projetos políticos e da correlação de forças em que ocorre, para além de envolver dimensóes teóricas e conceituais que vão desde as teorias da democracia e da participação, até às teorias organizacionais e aos modelos de governação e administração das escolas e respectivos sistemas escolares. Por essa razão, reconhecer o forte simbolismo político da gestão democrática, a sua genealogia revolucionária e as suas ligaçôes privilegiadas à democracia participativa não implica, em caso algum, deixar de estudar as suas dimensóes teóricas, de debater as suas realizaçóes práticas, rejeitando, por isso, definiçôes essencialistas e legalistas, tal como concepçóes de tipo meramente ideológico, participacionista e procedimentalista. De contrário, a gestáo democrática das escolas corre o risco de cristalização enquanto categoria pretensamente democrática e legitimadora, já relativamente desconectada de possíveis realizaçóes efetivamente democráticas em termos de governo das escolas, transformando-se num slogan, num lugar-comum que todos invocam sem consequências de maior, mesmo quando a definição dominante de gestão democrática possa revelar a sua eventual desvitalização, ou erosão, a subordinação perante a heteronomia e não o exercício da autonomia, ou uma concretização marcada por muita gestão (técnico-instrumental) para pouca democracia (substantiva). Com efeito, são muitos e consideravelmente divergentes os significados de gestáo democrática das escolas, categoria que, em vários contextos, atravessa hoje uma profunda crise.

\section{Três dimensões básicas associadas à gestão democrática das escolas}

Embora problematizável no plano teórico-conceitual, seja por referência aos conceitos de administração e de gestão escolares, em distintos contextos de recepção ${ }^{2}$, seja ainda por referência aos conceitos político-administrativos de governo, de direção e gestão (FORMOSINHO; FERNANDES, LIMA, 1988; BARROSO, 1995), é mais produtivo, para efeitos de estudo, inventariar e problematizar as principais dimensôes teóricas que são associadas ao conceito de gestão democrática, em estreita articulação com a análise das suas políticas e práticas, e com a emergência de sentidos divergentes, incluindo processos de erosão democrática e, mesmo, de crítica a partir de referenciais gestionários e eficientistas.

Constituindo-se e legitimando-se como uma contribuição indispensável ao processo de realização do direito à educação e à democratização das suas organizaçôes escolares, das suas estruturas, dos processos de decisão, das relaçóes de poder, das práticas educativas e de produção de conhecimento, dos direitos ao exercício da cidadania democrática e da participação ativa, não apenas por parte dos profissionais da educação, mas também, desde logo, dos educandos, das suas famílias, da comunidade, numa perspectiva de construção sociocomunitária da 
autonomia da escola, em direção ao seu autogoverno, a gestão democrática das escolas é realização de extraordinária exigência e dificuldade. É, por isso, realização passível de múltiplos graus de aprofundamento, de avanços e de recuos, de contradiçóes profundas, seguindo de perto os matizes teóricos da democracia e das suas distintas teorias, bem como as intensidades variáveis das práticas de participação e, no limite, de não-participação, nos processos de decisão.

Pesquisas realizadas ao longo das últimas três décadas no contexto das escolas portuguesas ${ }^{3}$ permitiram o estabelecimento de uma forte associação teórica entre gestão democrática e eleição, colegialidade, participação na decisão. Trata-se de três dimensóes consideradas cruciais, certamente associadas a outras também relevantes mas, em todo o caso, dependentes daquelas ou a elas subordinadas.

A eleição dos membros dos órgãos diretivos, dos principais detentores de cargos nas escolas e dos representantes dos vários corpos com participação nos processos de decisão representa um quesito considerado elementar, especialmente por contraste com a situação longamente vivida durante o regime autoritário e com os seus critérios de nomeação de órgãos unipessoais (reitores e diretores), tendo por base a confiança política entre governantes e personalidades nomeadas. De há muito que são debatidas as vantagens e os inconvenientes das três formas clássicas de escolha dos dirigentes escolares (eleição, concurso, nomeação, e ainda com possibilidade de recurso a uma combinação entre várias formas de designação). A eleição, estando em causa a escolha entre ideários ou distintos projetos político-pedagógicos para a escola é, do ponto de vista democrático, uma opção mais coerente, embora haja que atender a múltiplos fatores, com maior ou menor intensidade democrática, como os critérios de elegibilidade, a definição de eleitor, os processos eleitorais, a duração dos mandatos, as competências a exercer, sabendo-se que a simples eleição não pode ser considerada de forma atomizada e independente do grau de participação. É, todavia, uma regra nuclear da democracia e, nas escolas, também um testemunho e uma prática com potencial impacto numa educação para e pela democracia ${ }^{4}$, mesmo considerando que a competência técnica pode ser melhor garantida através do concurso e que a nomeação, em regimes democráticos, não é solução rara. Mas a eleição é democraticamente superior e, de resto, mais favorável à possível combinação entre práticas de democracia direta e práticas de democracia representativa nas escolas.

Quanto à colegialidade relativa aos órgãos de governo escolar, também mesmo em nível de gestão pedagógica intermédia, a experiência portuguesa ao longo de três décadas foi decisiva para a associação entre democracia e colegialidade, desde logo a partir das primeiras experiências de afastamento de reitores e diretores e da constituição de comissóes de gestão durante o período revolucionário e, depois da aprovação da Constituição de 1976, da eleição, sob regras muito detalhadas, de conselhos diretivos ${ }^{5}$, e mais tarde de conselhos executivos, até 2008, de acordo com a legislação ordinária. A existência de órgáos colegiados, como os conselhos 
diretivos $^{6}$, compostos por representantes eleitos dos docentes, dos alunos e dos funcionários, ou dos atuais conselhos gerais, estes já com participação alargada a representantes dos pais, da comunidade e do poder municipal (uma vez que náo há escolas municipais no país), poderá constituir uma alternativa democrática de grande alcance, sobretudo se a participaçáo nos processos de decisão puder ocorrer nas escolas, assim dotadas de certa autonomia e inseridas num contexto de administração escolar de tipo descentralizado. E, ainda, num contexto organizacional em que a presidência de tais órgãos coletivos assume funções de coordenação, mas não se configura como órgão unipessoal dotado de competências próprias que excedam aquelas que, geralmente, são atribuídas à presidência de órgãos colegiados. Embora objeto de controvérsia, a opção pela colegialidade dos órgãos é considerada mais próxima de concepçóes democráticas de pendor participativo, afastando-se de modalidades unipessoais, hoje fortemente conotadas com o exercício da liderança por parte de um executivo eficaz e, também, das alternativas mais típicas da burocracia monocrática exercida por funcionários profissionais sob a direção de um só chefe, conforme observou Max Weber (1984).

Finalmente, a participação na decisão emerge como uma dimensão central da gestão democrática das escolas, não apenas pelos fenómenos de participação ativa que são típicos dos processos de organização e mobilização democráticas, mas também porque a participação verdadeira exige muito mais do que o acesso à informação e o direito a ser informado, a publicidade democrática dos atos, as propostas e sugestóes, as auscultaçóes e outros processos eventualmente despojados de poder de decisão, que Maurício Tragtenberg (1989) designou de "participacionismo”. Pelo contrário, só o poder de decidir confere pleno sentido às práticas de governo democrático das escolas, rompendo com encenaçóes participativas, com rituais, processos e métodos formalmente democráticos, mas a que falta substantividade democrática. A governação democrática não se limita ao cumprimento das regras e dos processos democráticos, por mais relevantes que estes também sejam, nem reproduz necessariamente as regras procedimentais e outras, uma vez que pressupóe um quadro de autonomia, isto é, um regime em que é possível, ao menos parcialmente e no respeito pelo quadro constitucional e jurídico público, construir as próprias regras (auto+nomos), certamente em coautoria com outras instâncias governativas superiores, mas definitivamente de forma não inteiramente subordinada às regras dos outros (heteronomia), podendo mesmo chegar à prática de atos administrativos definitivos e executórios. Nesse contexto, todas as formas de "pseudoparticipação" são criticáveis, tal como, entre outros, observou Carlos Nuñez (1999)7 ; participar é decidir, e codecidir, e implica o exercício legítimo da capacidade de "ingerência, como, por sua vez, assinalou Paulo Freire (1967, p. 92). O poder de decidir, participando democraticamente e com os outros nos respectivos processos de tomada das decisóes representa o âmago da democracia e, consequentemente, sem participação na decisão não é possível conceber uma gestão democrática das escolas na perspectiva do seu autogoverno. É mesmo essa 
dimensão político-participativa decisória que confere sentido e substância às anteriores dimensôes de eleiçấo e de colegialidade democráticas.

\section{Alguns sentidos divergentes de gestão democrática}

Com base nas três dimensóes propostas e nas suas diversas possibilidades de articulação teórica e prática, é possível inventariar vários sentidos divergentes da categoria "gestão democrática das escolas", não apenas marcados pela miscigenaçáo de elementos teóricos e conceituais distintos, mas também por concretizações históricas e político-educativas mais próximas, ou mais distantes, dos ideais democrático-participativos, não raramente remetendo para situações de marcado hibridismo e mesmo para cenários de possível rutura com os valores da democracia. Considerando os limites deste texto, optou-se pela apresentaçáo breve de apenas três sentidos, ou concepçóes, de gestáo democrática das escolas, admitindo-se que a presente proposta teórico-metodológica possa ser objeto de desdobramentos e aprofundamentos vários, especialmente quando confrontada com exercícios de interpretação de políticas e de práticas concretas de governo das escolas, em determinados contextos e momentos históricos. Em tais circunstâncias, mais do que de uma simples aplicação da proposta e dos respectivos sentidos - ancorados em pesquisas sobre as escolas portuguesas que aqui são apresentadas de forma relativamente esquemática e estilizada -, ou do ato de os submeter à prova e de os confrontar teórica e empiricamente com as realidades a pesquisar, será da afinação, da adaptação mais ou menos profunda, ou mesmo da sua rejeição e superação que, certamente, se tratará.

\section{a) Autogoverno democrático}

Entendida como autogoverno democrático, a gestão democrática das escolas assume uma feição política, em busca da sua autonomia, em regime de co-decisão e de interdependência com outras autoridades públicas, legitimando a descentralizaçáo do sistema escolar e a transferência de poderes, do centro para as periferias, através da participação democrática dos atores escolares e do público em contato com a escola, numa perspectiva sociocomunitária. Não se trata, portanto, de uma simples transferência de poderes do ministério, do estado ou do município, por exemplo, beneficiando apenas os professores e outros educadores profissionais. Trata-se da construção de uma escola governante ${ }^{8}$, inserida numa rede pública cuja organização, provisão e manutenção é responsabilidade do Estado (independentemente da organização político-administrativa de cada país e dos seus diferentes níveis). No âmbito de uma política educativa nacional, haverá necessariamente tempo e lugar à produção de importantes decisóes escolares, e 
não apenas de tipo executivo, implementativo ou operacional, muito especialmente nos domínios científicos e pedagógicos, na gestão do currículo e da avaliação, na organizaçáo do trabalho docente e discente para a tomada de decisóes em contexto de diversidade social, cultural e de todos os tipos, hoje cada vez mais presente na escola democrática e só passível de abordagem através da prática da decisão, individual e coletiva, por parte dos educadores profissionais mas também, em múltiplas áreas, por parte de todos os outros atores socioeducativos.

Nesse contexto, os órgãos colegiados, democraticamente eleitos e democraticamente escrutinados, exercem uma autonomia assente na participaçáo ativa, no debate e no diálogo, em práticas de democracia direta, sempre que possível e adequado, e em práticas de democracia representativa, assim reforçando o autogoverno escolar e a autogestão pedagógica, inscrevendo-se numa política e num sistema escolar nacional, mas favorecendo a diversidade de práticas e os processos de deslocação do poder para as escolas. No contexto de uma gestão democrática instituinte, a escola é organizacionalmente interpretável de formas diversas, incluindo a de sistema ou arena política, onde coexistem interesses e agendas diversas, mas também a de comunidade educativa capaz de dirimir democraticamente os seus conflitos, exigindo do Estado o cumprimento dos seus deveres, abrindo-se à comunidade local e aos não-especialistas, até como forma de ampliar e reforçar politicamente os discursos pedagógicos e as vozes de educadores e educandos, no quadro de relaçóes de poder que são, tradicionalmente, bastante assimétricas e em desfavor das escolas e dos seus membros.

A conjugação de processos eleitorais democráticos, da colegialidade dos órgãos e da participação nos processos de decisão concorre para a transformação da escola num locus de produção de políticas, de orientaçóes e de regras, de decisóes e ações, à margem das quais não será possível a desalienação do trabalho escolar e a edificação de uma escola mais democrática e em permanente processo de aprofundamento da sua autonomia, pois uma escola mais democrática é, necessariamente, uma escola mais autónoma e com capacidade de autogoverno em vastas áreas.

\section{b) Estruturas e procedimentos democráticos}

A gestão democrática das escolas é, nesta concepção, associada, e em boa parte limitada, à existência de estruturas organizacionais democráticas e de procedimentos e regras democráticos. Tais elementos são de grande relevância no sentido de viabilizar as práticas democráticas e participativas, mas em nenhum caso podem substituir, ou minorar, a importância daquilo que é crucial e substantivo: a democratização dos poderes educativos através do exercício da tomada de decisóes nas escolas. Quando essa inversão de importância ocorre, é comum a crítica ao formalismo da democracia, à sua tendência para se fixar em métodos, regras e 
rituais, frequentemente usados pelos atores iniciados e pelas elites para dificultar a participação dos outros. $\mathrm{O}$ exagero do apego aos procedimentos, em prejuízo dos valores e dos objetivos democráticos, é conhecido por procedimentalismo, ou seja, a democracia estaria confinada a um "método político" e a um "arranjo institucional" que fossem capazes de viabilizar decisões políticas, conforme sustentou Joseph Schumpeter (1984), partindo da lei da mediocridade das massas e de uma concepçáo reducionista de democracia enquanto forma de competição entre líderes. Nas escolas, alguns desses fenómenos tendem a ocorrer, historicamente, quando se transita de uma gestáo democrática instituinte e em processo de construção, para uma gestão democrática instituída, formalmente consagrada em termos legislativos, ou já institucionalizada, sobretudo nos casos em que o poder de decisão, outrora deslocado para as escolas, foi novamente deslocado, mas para retornar ao tradicional centro político-administrativo.

A centralização da educação, seja de tipo concentrado ou desconcentrado, revela-se, então, em contradição profunda com as possibilidades de uma gestão democrática das escolas: escolas, ao invés, governadas e fortemente administradas, nas quais os discursos de autonomia tendem a assumir uma condição retórica ante a manutenção da centralização, ou mesmo perante a recentralização dos poderes educativos. Embora passível de ser decretada no plano das orientaçôes para a ação, a autonomia das escolas dificilmente poderá vir a ser praticada no plano da ação, sendo transformada numa espécie de autonomia heterogovernada, sitiada pela centralização do poder que sobre ela se abate de forma constante e asfixiante, por processos intrusivos de microgestão e de controlo remoto, designadamente eletrónico, ou então por modalidades de regulação baseadas no mercado, na competição entre fornecedores e nas teorias da escolha pública. A formalizaçáo e burocratização, seja nos casos de recentralização estatal, seja mesmo nos casos de descentralização e de autonomia de tipo mercantil e gerencialista, bem como a gestão escolar enquanto instrumento de dominação, surgem como algumas das mais pertinentes abordagens teóricas interpretativas.

Nesses contextos, as práticas de participação passiva e de não-participação tendem a emergir com grande impacto, mesmo relativamente a formas mínimas de democracia representativa em nível escolar, uma vez que a eleiçáo dos órgãos perde significado e que a colegialidade, quer seja mantida, quer seja abandonada, não mantém já relação com um poder de direção das escolas porque, verdadeiramente, esse poder se situa fora, e acima, delas, configurando uma direção escolar atópica, ou fora do seu lugar. Na prática, os atores escolares elegem os seus representantes e, eventualmente, órgãos colegiados, para que esses venham a impor-lhes políticas e regras heterónomas, produzidas pela direção externa das escolas, a quem representam junto da comunidade escolar, embora eventualmente eleitos por essa. 


\section{c) Gestão irracional e défice de liderança}

Sob influência da Nova Gestão Pública e das suas orientações gerencialistas ${ }^{9}$, as últimas décadas têm revelado crescentes críticas dirigidas à gestão democrática das escolas, sobretudo quanto aos seus elementos eleitorais e seus órgáos colegiados, agora associados a uma irracionalidade em termos de gestáo e a uma desresponsabilização e a um défice de liderança (unipessoal). Os conceitos de eficácia e de eficiência que são predominantemente assumidos por tal concepção evidenciam uma origem económica e gestionária, de tipo racionalista e técnico-instrumental. Nesses termos, a escola é apresentada como uma organização demasiado importante no contexto da economia do conhecimento e da produção de habilidades competitivas para que possa continuar subordinada a certos critérios democráticos que, por definição, são lentos, imprevisíveis e consumidores de recursos, não garantindo o alcance das melhores decisões técnicas. Mesmo admitindo que as escolas não são exatamente empresas, isso não significa que possam desprezar as melhores práticas da gestão empresarial, uma vez que essa é representada como racionalmente superior, inovadora e empreendedora. A gestáo democrática, ou provaria ser capaz de garantir uma alta eficiência e eficácia em termos de gestão racional - o que é considerado improvável -, ou deveria ser liminarmente afastada, especialmente no que se refere a processos eleitorais e relativos a colegialidade, uma vez que os órgãos colegiados são associados à desresponsabilização e à lentidão dos processos decisórios e que a liderança é entendida como a expressão de um líder individual, de um "rosto" ou "executivo eficaz" No limite, uma situação que, plausivelmente, se considera só ser possível de atingir através da ação de gestores profissionais de carreira, devidamente assessorados por tecnoestruturas próprias das escolas, ou partilhadas entre elas.

Isso não significa, necessariamente, uma rutura total e imediata com certos elementos democráticos, até devido a necessidades de legitimação institucional das escolas. Implica, contudo, a contenção de práticas e exageros democráticos e participativos, agora subordinados ao direito de gerir por parte de líderes preparados e legitimados tecnicamente através do seu recrutamento por concurso. Numa fase de transição, pode-se admitir a prática da eleição, embora limitada a colégios eleitorais restritos, do tipo conselho de curadores, ou conselho geral, perante os quais o diretor se assume como um diretor-geral (no caso de uma escola dotada de ampla autonomia), ou apenas como um executivo operacional, do tipo encarregado geral (em escolas com reduzida autonomia). Em todo o caso, o responsável máximo da escola deve responder diretamente e em primeiro lugar perante as autoridades que o contrataram, segundo objetivos claros e passíveis de avaliação e de prestação de contas, incluindo a prestação de contas interna perante os representantes dos interessados (stakeholders), os quais devem estar suficientemente (o que em certos casos já significa maioritariamente) representados no órgão 
escolar máximo, substituindo parcialmente os atores escolares e, também em casos já comprovados, passando a assumir a presidência do órgão político-estratégico.

$\mathrm{O}$ diretor escolar passa a concentrar mais poderes sobre o interior da escola, a nomear e a demitir livremente os detentores de outros cargos e a ser responsabilizado perante as autoridades e o órgão de topo pelos resultados da sua gestão, com destaque para a produção de resultados escolares mensuráveis e comparáveis através de modalidades de avaliação externa estandardizada.

Nesse quadro de referência político-gestionário, torna-se racional, e imperativo, adotar os modelos de governação e as técnicas de gestão que garantam o alcance dos mais elevados padróes de eficácia e eficiência, de competitividade e atratividade, de inovação e diferenciação das escolas, segundo o cânone gerencialista. Perante uma representação teórica mecanicista e burocrática, centrada nos meios e em busca da solução ótima, parece claro que, em caso de conflito entre democracia e eficácia, passará a ser preferível optar pela segunda e refrear, ou abandonar, a expressão da primeira.

\section{Gestão democrática ou pós-democracia gestionária?}

A intensidade democrática e participativa das realizaçóes que são passíveis de associação à categoria "gestão democrática das escolas" tem conhecido situaçóes de grande diversidade ao longo das últimas décadas mas, em geral, orientadas para a erosão, ou mesmo para o ocaso, da democracia nas escolas. De certo modo, a democracia educacional vai-se tornando tão invisível, mesmo apenas enquanto discurso político, quanto a democracia económica e industrial, por exemplo, um tópico que, na década de 1970, se encontrava pujante em termos de debate, reivindicação e experimentação social em vários países, sobretudo nos países nórdicos.

Em geral, na Europa e em países de outros continentes em que a educação tem sido objeto de reformas a partir da concepção de um Estado gestionário, supervisor e avaliador, introduzindo-se novas modalidades de governaçáo da educação através de parcerias com o terceiro setor, da instituição de mecanismos de concorrência entre o público e o privado $^{11}$, de gestão centrada nos resultados escolares e numa racionalização das redes escolares, a par de processos de grande deterioração das condiçóes de trabalho nas escolas e de recentralização do poder, motivados por políticas de austeridade e de ajustamento económico, como as que ocorrem na Europa do sul, o governo democrático das escolas não apenas surge como uma preocupação deslocada, fora de tempo e das prioridades políticas, mas sobretudo associada ideologicamente a uma irresponsabilidade em termos de gestão racional, eficaz e eficiente dos estabelecimentos de ensino. A 
democracia política garantiria, desde logo, o funcionamento e a legitimidade dos sistemas escolares, a partir do momento primordial das respectivas eleiçóes, concedendo autoridade democrática aos governantes eleitos, nos seus diversos níveis político-administrativos de atuação, pelo que as escolas seriam, a partir de então, instrumentos técnico-racionais ao serviço das políticas, dos valores e dos objetivos vencedores. Nesse quadro, a democracia política e a competição entre líderes e elites políticas passam a exaurir o repertório de possibilidades do exercício democrático e a autonomia das escolas fica limitada a escolhas operacionais, de execução competente e competitiva das orientaçóes superiores e das políticas heterónomas. A descentralização educativa é, sobretudo, devoluçáo de responsabilidades e encargos, bem como abertura ao setor privado, o qual, de resto, pode vir a ser beneficiário da concessão da própria gestão das escolas públicas, como acontece já, há vários anos, em alguns países. Nesse contexto, a gestão democrática das escolas seria uma contradição, um paradoxo inesperado.

O crescente elogio da liderança unipessoal das escolas, que, como nas empresas, seria responsável pela apresentação de uma visão, de um projeto e de uma equipa, a que o conselho de curadores ou o conselho geral, consoante os modelos (em certos casos admitindo a escolha por eleição, limitada aos membros desse conselho), daria a sua confiança e avaliaria no final do mandato, podendo reconduzir, sem eleição, a liderança, caso estivesse satisfeito com o seu desempenho, como prevê, por exemplo, a atual legislação portuguesa no ensino básico e no ensino secundário, revela a desvalorização dos processos eleitorais e da natureza colegial dos órgãos de direção e gestão. Mas revela, sobretudo, como a maioria dos atuais discursos políticos em torno da descentralização e da autonomia se inscrevem fora de uma concepção democrática de governo das escolas, afastando a participação dos atores socioeducativos dos processos políticos de tomada das decisóes.

Eleição, colegialidade e participação na decisão surgem, agora, amplamente desvalorizadas enquanto dimensões básicas da gestão democrática das escolas. Não se trata, contudo, e na maioria dos casos, da opção por uma gestão autocrática, ou definitivamente não democrática, das escolas. Em primeiro lugar porque vários princípios constitucionais e ordenamentos jurídicos em vigor em diversos contextos o não permitem formalmente, dado que a antiga legislação não foi revogada e que, em certos casos, existem dificuldades, ou impedimentos de diverso tipo, para que tal venha a ocorrer. Em segundo lugar porque, embora a categoria gestão democrática tenha já sido isolada no plano jurídico-formal dos normativos historicamente marcados, tendo sido apagada dos recentes discursos reformistas e tendo perdido centralidade na legislação escolar atual, o elemento democrático, ainda que de intensidade baixa e de alcance restrito, cumpre requisitos mínimos de legitimação e permite justificar a abertura da educação escolar e das respectivas organizaçóes a novos atores socias e interesses económicos. 
A generalizada desafeição perante a democratização do governo das escolas, perante a colegialidade dos seus órgãos de verdadeira direção tópica e perante a participação nos processos de decisão político-educacional, não é, porém, totalmente incompatível com um módico de democracia restrita a elites, atores iniciados, representantes de empresários e de outros setores interessados. Setores sociais que são capazes de exigir das escolas a satisfação das principais necessidades de formação das qualificações e das competências consideradas essenciais à promoção do empreendedorismo e da empregabilidade, da competitividade económica e da produtividade, da flexibilidade laboral e da adaptação funcional dos indivíduos às condiçóes de incerteza e de precariedade no novo capitalismo.

Naqueles termos, uma gestão pós-democrática das escolas, baseada nos valores da racionalidade económica, da competitividade e da inovação, sob comando dos princípios gerencialistas que têm sido introduzidos na administração pública ao longo das últimas décadas, pode representar uma solução de compromisso, rejeitando soluçôes definitivamente não democráticas, mas, ao mesmo tempo, instituindo mínimos democráticos compatíveis com a ação das elites políticas, económicas e filantrópicas, dos novos interesses organizados, das potenciais fontes de financiamento, dos gestores escolares e das suas tecnoestruturas de assessoria, dos consultores externos e das firmas de prestação de serviçôes. $\mathrm{Na}$ "economia do conhecimento" e na "sociedade da aprendizagem" existem muitas oportunidades para as escolas economicamente orientadas e comprometidas, capazes de estabelecer parcerias proveitosas e de realizar aprendizagens organizacionais baseadas na cultura de empresa, nas técnicas do marketing e da publicidade.

A ascensão de uma pós-democracia nas escolas públicas, com algumas semelhanças ao que Colin Crouch (2004, p. 22) observou no caso da pós-democracia política, concede primazia ao mundo empresarial - que é tomado como modelo a seguir -, aos clientes e consumidores, aos consultores e aos lobistas, perante uma representaçáo de passividade e de não participação por parte dos atores escolares, uma fraca qualidade democrática da vida escolar, um desinvestimento em políticas igualitárias e redistributivas, uma incapacidade deliberada para limitar os interesses dos atores sociais mais poderosos, uma diabolização dos sindicatos, uma desvalorização, sem precedentes, do pensamento pedagógico, da pesquisa educacional e dos saberes profissionais dos professores.

A gestão democrática das escolas, enquanto autogoverno democrático e, em boa parte, até mesmo enquanto conjunto de estruturas e de procedimentos democráticos, foi objeto de uma crítica sistemática por parte de setores políticos que concebem a democracia no governo das escolas como um exemplo dos desmandos progressistas na educação e da irresponsabilidades das lideranças colegiadas, que ainda é possível encontrar em certas organizaçóes públicas. Organizaçōes a que ainda não teriam chegado com suficiente intensidade os ventos modernizadores e racionalizadores da Nova Gestáo Pública, apesar das marcas que essa ideologia 
gestionária tem deixado nas escolas, de forma indelével, segundo a pesquisa disponível. Nesse processo de reforma das escolas, das suas estruturas de governo e da organização do trabalho docente, a opção por uma pós-democracia gestionária parece uma alternativa teórica e ideologicamente congruente, de que é possível encontrar múltiplos sinais, justificando-se, por isso, estudos nessa linha de indagação, procurando obter respostas para a interrogação formulada no título atribuído ao presente texto, ou iniciando as pesquisas através da assunção dessa hipótese de trabalho.

\section{Notas}

1. Este trabalho foi financiado por Fundos Nacionais através da FCT - Fundação para a Ciência e a Tecnologia no âmbito do Projeto PEst-OE/CED/UI1661/2014.

2. Versando embora problemáticas que vão muito para além da discussão de conceitos, são trabalhos seminais e de elevado interesse para esta matéria as obras de Félix (1984) e de Paro (1986). Veja-se, também, o debate e a síntese sobre a situação no Brasil apresentados por Souza (2006) e por Drabach e Mousquer (2009).

3. Para uma síntese ver, especialmente, os dois primeiros capítulos de Lima (2011).

4. O tema da educação para a democracia através do exercício da cidadania e da participação democrática é, pelo menos desde Rousseau, um tema clássico, como entre outros autores destacou Carole Pateman (1970). No campo da educação, a partir da influência da Escola Nova e de John Dewey, autores como António Sérgio (em Portugal) e Anísio Teixeira (no Brasil), criticaram a burocratização das escolas e propuseram a sua democratização ou a criação de uma escola progressista, tendo Sérgio (1984) defendido o "selfgovernment escolar", na sua obra intitulada Educação Cívica, publicada originalmente em 1915. A mesma questáo é objeto de análise, no campo de uma sociologia política da educação, por parte de Raymond Morrow e Carlos Alberto Torres (1997) e, no Brasil, destaca-se a extensa obra de Paulo Freire, desde Educação como Prática da Liberdade (FREIRE, 1967), à luz de uma concepção de democracia radical na educação e na organização escolar, que estudei em Lima (2013a).

5. Note-se que essa designação foi legalmente instituída pela primeira vez no final de 1974 (PORTUGAL, 1974b), embora regulamentada com pormenor e no quadro de uma concepçáo de democracia representativa nas escolas, em boa parte subordinada aos serviços centrais do ministério da educação, após a publicação do Decreto-Lei no 769-A/76. (PORTUGAL, 1976)

6. Observe-se que também Vitor Paro, no seu estudo sobre a eleição de diretores escolares, após concluir que é necessário desvincular os diretores das suas marcas tradicionais de chefes, ou de burocratas, sugere que a direção das escolas poderia ser exercida por um colegiado que designa de "conselho diretivo", substituindo assim a figura de diretor e propondo que aquele novo órgão coletivo tivesse um "coordenador geral" que assumisse a sua presidência. (PARO, 1996, p. 132) Em Portugal, a partir da legislação de 2008 (PORTUGAL, 2008), os anteriores conselhos foram substituídos por um diretor, enquanto órgão unipessoal, remetendo a colegialidade exigida pela Constituição para um conselho geral, um órgão efetivamente representativo, que passa a eleger o diretor, mas que está longe de poder ser considerado como o verdadeiro órgão de "direção estratégica" das escolas, ao contrário do que sustenta o legislador.

7. Escreveu este autor: "[...] participação é ter a capacidade de decidir, controlar, executar e avaliar os processos e seus projetos; se não há capacidade de decisão e de controlo, estaremos a falar no máximo de uma participação reativa... mas nunca substantiva”. (NUNEZZ HURTADO, 1999, p. 220)

8. Aplica-se aqui à escola a distinção proposta por Georges Burdeau (1975, p. 32-39) entre "democracia governante" e "democracia governada".

9. Apesar da abundante literatura disponível sobre esta matéria destaca-se aqui o trabalho marcante de John Clarke e Janet Newman (1997) sobre o Estado gerencial, ou gestionário, e no campo espe- 
cífico das escolas o trabalho incontornável organizado por John Smyth (1993) e a sua mais recente crítica à gestáo centrada na escola em vários países. (SMYTH, 2011)

10. Ver, a este respeito, o estudo que publiquei no Brasil sobre a generalização, em Portugal, desde 2008, da figura de diretor e respectivas análises e hipóteses de trabalho (LIMA, 2013b). Para um ensaio comparativo mais global, entre Brasil e Portugal, veja-se o trabalho de Donaldo Souza e Dora Castro (2012).

11. No caso específico do Brasil, de entre a literatura disponível destaco a obra organizada por Theresa Adriáo e Vera Peroni (2008), autoras que mantêm há vários anos uma linha de pesquisa nesta área.

\section{Referências}

ADRIÃO, T.; PERONI, V. (Orgs.). Público e privado na educação: novos elementos para o debate. São Paulo: Xamã, 2008.

BARROSO, J. Para uma abordagem teórica da reforma da administração escolar: a distinção entre "direcção" e "gestáo". Revista Portuguesa de Educaçâo, Braga, v. 8, n.1, p. 33-56, 1995.

BURDEAU, G. A democracia: ensaio sintético. Mem Martins: Publicações Europa-América, 1975.

CLARKE, J.; NEWMAN, J. The managerial state. Power, politics and ideology in the remaking of social welfare. Londres: Sage, 1997.

CROUCH, C. Post-Democracy. Cambridge: Polity Press, 2004.

DRABACH, N. P.; MOUSQUER, M. E. L. Dos primeiros escritos sobre administração escolar no Brasil aos escritos sobre gestão escolar: mudanças e continuidades. Currículo sem Fronteiras, v. 9, n. 2, p. 258-285, jul. 2009. Disponível em http://www.curriculosemfronteiras.org. Acesso em: 27 out. 2014.

FÉLIX, M. F. C. Administração escolar: um problema educativo ou empresarial? São Paulo: Cortez e Autores Associados, 1984.

FORMOSINHO, J.; FERNANDES, A. S.; LIMA, L. C. Princípios gerais da direcção e gestão das escolas. In: CRSE-Comissão de Reforma do Sistema Educativo. Documentos preparatórios II. Lisboa: Ministério da Educação, 1988. 139-170.

FREIRE, P. Educação como prática da liberdade. Rio de Janeiro: Paz e Terra, 1967.

GHANEM, E. Educação escolar e democracia no Brasil. Belo Horizonte: Autêntica/Ação Educativa, 2004.

GRÁCIO, R. A educação, dez anos depois. Que transformaçóes, que rupturas, que continuidade? Revista Critica de Ciências Sociais. Coimbra, n. 18/19/20, p. 153-182, 1986.

LIMA, L. C. Gestão das escolas secundárias. A participação dos alunos. Lisboa: Livros Horizonte, 1988. 
LIMA, L. C. A escola como organização e a participação na organização escolar. Braga: Universidade do Minho, 1992.

E depois de 25 de abril de 1974. Centro(s) e periferia(s) das decisóes no governo das escolas. Revista Portuguesa de Educação, Braga, v. 12, n. 1, p. 57-80, 1999.

Administração escolar: estudos. Porto: Porto editora, 2011.

Organização escolar e democracia radical. Paulo Freire e a governação democrática da escola pública. 5. ed. São Paulo: Cortez, 2013a.

Diretor(a) de escola pública: unipessoalidade e concentração do poder no quadro de uma relação subordinada. In: PERONI, V. (Org.). Redefiniçôes das fronteiras entre o público e o privado: implicações para a democratização da educação. Brasília: Liber Livro, 2013b, p. 58-81.

MORROW, R. A.; TORRES, C. Teoria social e educação. Uma crítica das teorias da reprodução social e cultural. Porto: Afrontamento, 1997.

NÚNEZ HURTADO, C. La revolución ética. 2. ed. Guadalajara: Instituto Mexicano para el Desarrollo Comunitario, 1999.

PARO, V. H. Administração escolar: introdução crítica. São Paulo: Cortez/Autores Associados, 1986.

1996.

Eleição de diretores. A escola pública experimenta a democracia. Campinas: Papirus,

PATEMAN, C. Participation and democratic theory. Cambridge: Cambridge University Press, 1970.

PORTUGAL. Decreto-Lei n. 221/74, de 27 de maio de 1974. Regula a gestão dos estabelecimentos de ensino. Diário da República, 1974a.

Decreto-Lei n. 735-A/74, de 21 de dezembro de 1974. Institui a gestáo democrática dos estabelecimentos de ensino preparatório e secundário. Diário da República, 1974b.

Decreto-Lei n. 769-A/76, de 23 de outubro de 1976. Institui a gestão democrática dos estabelecimentos de ensino preparatório e secundário. Diário da República, 1976.

Decreto-Lei n. 75/2008, de 22 de abril de 2008. Regime de autonomia, administração e gestão dos estabelecimentos públicos da educação pré-escolar e do s ensinos básico e secundário. Diário da República, 2008.

SCHUMPETER, J. A. Capitalismo, socialismo e democracia. Rio de Janeiro: Zahar, 1984.

SÉRGIO, A. Democracia. Lisboa: Livraria Sá da Costa Editora, 1974.

SMYTH, J. The disaster of the "self-managing school" - genesis, trajectory, undisclosed agenda, and effects. Journal of Educational Administration and History, v. 43, n. 2, p. $95-117,2011$.

1993.

(Org). A socially critical view of the self-managing school. Londres: The Falmer Press, 
SOUZA, A. R. Perfil da gestão escolar no Brasil. 2006. 302f. Tese (doutorado), Pontifícia Universidade Católica de São Paulo, São Paulo. 2006

SOUZA, D. B.; CASTRO, D. F. Gestão democrática da educação sob perspectiva comparada Brasil-Portugal: entre a exigência legal e a exequibilidade real. Educaçâo \& Sociedade, Campinas, v. 33. n. 121, p. 1195-1213, out./dez. 2012.

STOER, S. R. Educação e mudança social em Portugal. 1970-1980, uma década de transição. Porto: Afrontamento, 1986.

TRAGTENBERG, M. Administração, poder e ideologia. São Paulo: Cortez Editora, 1989

WEBER, M. Economía y sociedad. Esbozo de sociologia compreensiva. México, D. F.: Fondo de Cultura Económica, 1984.

Recebido em 11 de novembro de 2014.

Aprovado em 27 de fevereiro de 2015. 